\title{
Palestra
}

\section{A ontologia de Lukács: contaminação idealista do marxismo ${ }^{1}$}

\section{João Quartim de Moraes *}

Meu boa noite a todas e todos, meus agradecimentos aos organizadores desse ciclo de debates, Evaristo, Silvia e aos demais membros da coordenação dos estudos de pós-graduação que viabilizaram esse encontro.

Sem outro preâmbulo, eu apresento o tema que pretendo expor e submeter a debate, questões, questionamentos: a contribuição do marxismo para compreensão do homem. Que vivente, que tipo de vivente é o homem, cuja espécie prevaleceu sobre as outras e assumiu para o bem ou para o mal, o domínio do planeta.

Se nós perguntamos quem é o homem, as religiões, e mesmo as filosofias, as metafísicas, têm respostas prontas, e há muito tempo.

As respostas variam, dependendo da natureza ou teológica ou metafísica das respostas. Mas sempre giram em torno de alguns preceitos, de alguns princípios, que nós todos estamos cansados de conhecer, de ter ouvido: o homem é um animal racional; o homem foi criado por Deus à sua imagem e semelhança. Só que essa semelhança relativa, no caso da teologia cristã, porque ao mesmo tempo o mal está aí. O espetáculo da vida humana é um espetáculo que pode ser exaltante,

\footnotetext{
${ }^{1}$ Palestra proferida na Universidade Estadual de Londrina (UEL) em 9 de março de 2013 durante evento "MARXISMO: DEMOCRACIA E DIREITOS HUMANOS" promovido pelo Programa de Pós-Graduação em Serviço Social e Políticas Sociais, Grupo de Pesquisa Serviço Social e Sistema Sociojuridico e Grupo de Pesquisa Processos de Trabalho do Serviço Social.

*Professor da Faculdade de Filosofia da UNICAMP. jqmoraes@gmail.com
} 
em múltiplos aspectos, encorajador da vontade de viver, de participar, mas às vezes é um espetáculo também cruel, deprimente. Bem e mal se entrecruzam na história da humanidade.

As teologias têm essa facilidade: encontram uma resposta, que não precisa ser demonstrada, basta apelar para o mito. Eu digo mito num sentido que não é pejorativo, mas meramente descritivo. A palavra mito vem do grego clássico e quer dizer "história", "fábula". Uma fábula mesmo. Então os mitos, as fábulas, eram historinhas com conclusões a tirar. Por exemplo, eu começo contando uma pequena fábula de Esopo, que foi o grande autor do gênero, e viveu cerca de 500 anos antes de nossa era.

O velho e a morte. Um homem muito velho, cansado, camponês, foi buscar lenha. Era frio, precisava de lenha. Para cozinhar e também para se aquecer. Ele morava num pequeno rancho, em cima de uma colina. Ele estava muito cansado. Aquele feixe de lenha pesava muito no ombro dele, está doendo. Velho sempre tem qualquer coisa, mexe um pouco e já fica com dor aqui, dor ali. Isso faz parte do envelhecimento. E ele olha, lá de baixo, a distância que tinha de subir para chegar até a casinha dele. E num momento de fraqueza, ele diz: seria melhor a morte. Mal disse isso, apareceu caveira, vestida a caráter, com a foice na mão: - Você me chamou? O que você quer? - Eu quero que a senhora me ajude a carregar este fardo até lá em cima.

O pecado original é um outro mito, agora um mito cristão. Para explicar o mal do mundo e a maldade humana, a crueldade, contam uma história, que o homem está manchado pelo pecado original. Assim já se tem a explicação para todos os males que ocorrem com a humanidade.

Depois desse pequeno prelúdio de fábulas, mas sempre no sentido de aproximar uma reflexão filosófica da nossa experiência corrente, expressa em nossa linguagem corrente, proponho uma pergunta, cuja resposta parece meio óbvia, mas dá o que pensar. É uma pergunta embutida numa frase extremamente simples: "A tortura é desumana”. É irônica essa frase, porque o único vivente, o único animal que tortura é o homem. Então a tortura é humana, e não desumana. Ela é uma invenção do homem.

Portanto não é preciso grandes digressões, não é preciso grandes conceitos filosóficos, desses que impressionam como "ontologia do ser social", e outros que circulam por aí, para fazer compreender que há um problema com essa noção de humanidade. Em relação a que a tortura é desumana? Em relação a que vivente? Não, a tortura é uma invenção do homem, que atravessa a história humana. 
Outra coisa é que nós queiramos suprimi-la, que nós a condenemos, que nós a consideremos ignóbil, um crime inafiançável. Um crime inafiançável e hediondo, mas que continua a ser praticado por aí.

Podemos também pensar em frases semelhantes que suscitam o mesmo tipo de raciocínio. Por exemplo, o governador de São Paulo, um senhor de direita, que justificando um dos massacres que a PM cometeu disse: "Quem não se mexeu não morreu". Sabemos que nem isso é verdade, mesmo quem ficou quieto tomou tiro. Esse senhor gosta de dizer (e isso vale para Londrina, qualquer outra cidade): "Vamos tornar São Paulo uma cidade mais humana". O que quer dizer se tornar mais humano? Que humano é esse em relação ao qual se compara a conduta dos homens, tais como eles existem? É uma certa ideia abstrata de humanidade.

Com isso eu passo para meu argumento central: qual é a contribuição que o marxismo traz para a compreensão desse enigma humano? Não vou discutir a teoria econômica de Marx aqui, nem a política de Marx, vou discutir algo que está antes disso: que visão da condição humana o marxismo oferece? Que problemas isso traz? E, se houver tempo, se a exposição escorregar por aí, veremos as divergências entre marxistas sobre a interpretação da filosofia de Marx. Porque estamos longe, no terreno do marxismo, da unanimidade.

A primeira questão é: como surgiu o homem na natureza? Nós temos em cima disso 150 anos, pelo menos, de pesquisas arqueológicas de grande qualidade que desvendaram algo que, até 150 anos, era totalmente desconhecido. Quanto aos textos religiosos que afirmam que o homem surgiu há cerca de 5 ou 6 mil anos, não dá nem para discutir. Não quero agredir as crenças de ninguém, mas não dá para discutir. Conhecimento científico é aquele que faz com que, se nós temos uma doença séria, nós vamos a um hospital especializado, não vamos consultar um curandeiro. Quando nós precisamos, por exemplo de uma cirurgia, nessa hora nós acreditamos sim na ciência. Essa mesma ciência nos permite dizer que simultaneamente ao homo sapiens sapiens, a espécie biológica à qual nós pertencemos, viveu o homo sapiens neanderthalensis, que terá sido extinto há uns 30 ou 20 mil anos. O homem tem atrás de si, uma história de (enquanto espécie humana) de 40 ou 50 mil anos, ou quem sabe 100 mil anos. Se nós consideramos os primeiros homens, nós retrocedemos para 200, 300 mil anos. Se nós consideramos os hominídeos a história de nossa espécie, ou das origens de nossa espécie, pertencendo aos... ou melhor, para ser mais exato, a história do gênero homo, é uma história que já tem dois, três milhões de anos. homo erectus, por exemplo o homo sapiens sapiens, a espécie teve várias configurações. 
Como Marx considera essa história? Que imagem do homem ele nos oferece? E aqui impõese evocar uma polêmica, também dentro do marxismo: há duas, pelo menos duas concepções sobre o homem em Marx. Na primeira juventude, ele era influenciado pela filosofia das Luzes, da ilustração, por Hegel, e sobretudo por Feuerbach, que foi efetuou uma importante crítica da religião. Os que já ouviram falar de Feuerbach têm noção de que em seus escritos ele desenvolveu a ideia de que não foi Deus quem criou o homem, foi o homem que inventou Deus. Deus é a compensação imaginária da miséria humana, um ideal de humanidade que o homem projetou fora de si, num ser perfeito, absoluto etc. Fora de si, portanto alienado, e passa a ser outro no (outro?) de si mesmo. (...) um ideal de perfeição que não corresponderia às condições reais da existência, mas que eu projeto lá. Lá onde? No além, em Deus, no absoluto. Feuerbach discutiu muito esse esquema, é uma ideia que ele defendeu muito. É uma ideia interessante, é uma crítica da religião interessante, que evidentemente se chocou com as ideias estabelecidas, e nesse sentido fez uma grande contribuição.

Mas a concepção que ele tinha da condição humana concreta, digamos que deixava muito a desejar, porque estava muito marcada por uma especulação filosófica abstrata. Ele dizia: “Deus é a expressão da essência humana genérica", na verdade seria um ideal humano, um ideal de humanidade. O termo "essência humana genérica" traduz uma expressão alemã: Gattungswesen. A essência geral do homem. Essa essência não tinha existência, porque a condição efetiva do homem não é o ideal. Ao mesmo tempo, ele não admitia que essa essência fosse também mera especulação. O homem na sua origem, o homem essencialmente, no fundo de seu ser, ele é um ser genérico, ele diz, é um ser gregário, a humanidade é algo efetivo, real. E as contradições, as guerras, violências, destruições que nós testemunhamos na história humana são consequência de que o homem perdeu a sua essência, alienou sua essência, é explorado, ou melhor, é alienado, perdeu de vista a sua essência. O termo "exploração" adquiriu com Marx um sentido muito preciso, muito rigoroso, que eu não quero confundir aqui. O homem é um ser alienado, que a sua essência ele vê fora de si, no absoluto. Esse é o ponto.

Marx não aceitou exatamente isso. Algumas vezes, nessas primeiras obras, nos seus primeiros escritos, ele se referiu a essa essência genérica do homem, aí é mesmo uma influência de Feuerbach. Apenas ele introduziu, no pensamento de Feuerbach, um elemento que seria decisivo, que iria revolucionar o conhecimento da humanidade. Digamos assim, como na biologia, tal como ela existia, aparece alguém chamado Charles Darwin, que explicou os mecanismos básicos da evolução das espécies, das diferenças que nós encontramos entre os seres vivos, explicou o 
conceito de "seleção natural" e de mudança através da seleção natural, Marx colocando a categoria trabalho na base de sua reflexão, introduziu naquela especulação abstrata de Feuerbach, de uma essência genérica do homem, um elemento concreto, um elemento ativo, sobretudo: o trabalho. A principal expressão da essência do homem é trabalhar. Trabalhar quer dizer: imprimir na natureza formas úteis para si, e ao fazê-lo, e ao moldar a natureza segundo os seus objetivos, ele moldou-se a si mesmo. Esse é o ponto.

Donde o princípio do materialismo histórico, que é: o homem se autoproduziu pelo trabalho. A dificuldade começa, e aí começa também uma forte divergência no pensamento marxista, sobre essa questão básica: o homem se autoproduziu pelo trabalho. Estou propondo uma análise desse termo, uma análise rigorosa, lógica dessa afirmação, que, em princípio, é uma afirmação revolucionária, ela modifica aquela visão estática que Feuerbach tinha da essência humana alienada (...) como o homem se realiza, como o homem é reativa, (...) ele é ativo pelo trabalho. Isso é sua característica própria. E com essa característica ele se autoproduziu, se autodesenvolveu, desenvolveu sua história.

Mas aí há um problema lógico. Eu não diria que é um vício lógico, pois não chegamos a nenhuma conclusão ainda. Mas considerem essa sentença, essa tese: o homem se autoproduziu pelo trabalho. Há um momento que o homem ainda não tinha sido produzido. Era um protohumano, que trabalhava como os demais viventes, isto é, tirava do meio ambiente sua subsistência. Produzir é um processo. Tem o começo, o meio, tem o resultado. Mas enquanto o homem estava se autoproduzindo, ele ainda não era humano. Ficou humano trabalhando. Mas se os demais viventes também trabalhavam e nem por isso ficaram humanos, ao dizer que trabalhando, o homem se tornou homem caímos num círculo vicioso: ao trabalhar de modo humano ele estava cumprindo uma determinação que ele já tinha, ele já era homem.

As descobertas científicas de milhares e milhares de pesquisadores, descobertas que em certo sentido têm um estatuto científico tão forte que elas são trans-ideológicas, por exemplo, descobertas científicas de grande importância sobre a origem da linguagem, avançaram respostas mais concretas. De onde vem a fala humana, a capacidade de se comunicar por sons articulados?

Isso que é algo tão propriamente humano? Nossos mais próximos parentes, em termos de ADN, de composição genética, que são os chimpanzés, são rigorosamente incapazes de emitir sons articulados. E houve descobertas convergentes de estadunidenses, soviéticos e europeus, além do famoso inglês Leakey que estudou as primeiras configurações do hominídeo, há 3, 4 milhões de 
anos, com a famosa Lucy que ele descobriu lá no Quênia. Seria uma garota de uma primeira versão do homem que teria sido encontrada num estado de conservação razoável. O que a arqueologia e a antropologia arqueológica nos mostra, nos confirma é que esse processo foi muito longo. E que nesse processo, a dinâmica foi dada num complexo de fatores cumulativos, que vão dando certo, porque há linhas de evolução que dão errado, isto é, que tornam o vivente uma modificação de circunstâncias que não dão para se manter vivo. Outras espécies pereceram. Mas no caso da hominização, esse processo de 4 milhões de anos, cujo resultado foi, há 30 ou 40 mil anos foi essa espécie à qual nós pertencemos, a nossa espécie, e que acabou dominando o planeta, desenvolvendo exponencialmente suas capacidades cognitivas, e assim podemos desenvolver com objetividade, sem mitos, sem teses teológicas, com o olhar do conhecimento científico, essa evolução que levou a esse resultado.

Aliás, é que eu não vou levantar, senão em vez de ser um debate vira aula, às vezes até me dá vontade de fazer uns desenhinhos, mas a gente pode considerar que toda a evolução da vida, a partir das primeiras bactérias, podia ser representada por uma bolinha. Se a gente for representar uma bactéria, ou mesmo um vírus, os primeiros protozoários por uma bolinha, todos os unicelulares por uma bolinha, a gente vai ver que o desenvolvimento, a diferenciação dessas primeiras formas de vida iriam juntar uma outra bolinha, uma outra bolinha. Quem sabe algumas dessas bolinhas foram exterminadas, não deram certo, porque os fatores que presidem à evolução não são predeterminados. Do ponto de vista científico, não há nenhum progresso. Poderia não ter acontecido. Poderia ter vindo um asteroide, poderia ter arrebentado tudo, há um bilhão de anos atrás, quando a vida estava eclodindo, quando estavam começando a eclodir, no meio marítimo, as primeiras bactérias... algo há 3 ou 2 bilhões de anos. De modo que nada é garantido, e muitas espécies foram exterminadas.

Mas o fato é que aqueles que sobreviveram começaram a se diferenciar, a se tornar um organismo mais complexo, na hora em que passou a ter uma bolinha maior, com bolinhas menores em torno. Algumas bolinhas foram esticando, viravam patas, outras viraram cabeça. Grandes arqueólogos assim resumem a história dos seres vivos. Isso pode ser um esquema infantil. Mas evidentemente que a complexidade dos organismos pode obedecer a esse traço.

Para não perder de vista o nosso foco, o momento decisivo da hominização foi a chamada situação ereta, a marcha vertical. O que tampouco veio de uma vez só. E há múltiplas hipóteses até para explicar por que, no ramo dos primatas, que era o ramo do qual saíram os primeiros 
hominídeos, em algum momento, uns começaram a andar de pé. Se observarmos todos os outros, eles têm cauda, (há algum que não tem cauda? não), andam curvados, na sua grande maioria são arborícolas. Isso fez crer, e é a hipótese mais consistente sobre a primeira diferenciação: ela ocorreu quando certos primatas desceram das árvores, isso teria ocorrido entre 30 e 20 milhões de anos atrás

São hipóteses, hipóteses plausíveis que podem ou não ser confirmadas... estamos falando de ciência, e não de revelação mística ou coisa assim. Ciência, conhecimento. São essas as hipóteses que podem ou não ser confirmadas por descobertas arqueológicas mais para frente. Que virão, que certamente virão, pois os instrumentos de pesquisa vão se tornando mais precisos, mais abrangentes.

É a hipótese de que a grande concentração de primatas estava na África, numa época em que a África estava coberta, pelo menos uma região da África, a África central, a África oriental, estava coberta de compenetradas extensas florestas. E que por mudanças climáticas houve um decréscimo do número de árvores. É uma hipótese razoável, mudanças climáticas ocorrem. E um clima mais seco, falta de chuva, podem facilmente explicar uma mudança sensível do número de árvores.O efeito da diminuição do número de árvores para uma população dada de primatas, qual é? Torna mais dura a luta pela sobrevivência. A briga fica mais feia, pra comer coquinho, comer frutinha, comer folha etc., os choques começam a ser mais numerosos. $O$ morticínio também. Quem sabe um desses primatas, que teria sido nosso hipotético ancestral, era mais fraquinho, não podia encarar uma briga com um chimpanzé ou um antepassado dele. Era muito difícil para ele a concorrência, quando a concorrência ficou muito intensa.

Por que essa hipótese? Por que que certos primatas desceram da árvore? Descer da árvore era muito complicado, porque no chão o que é que tinha? Tinha leão, tinha tigre, tinha toda a fauna de grandes felinos, sempre com fome, com aquela fome perene. Também dava para catar alimentos no chão, tem raízes, frutas, pequenos animais mortos, porque não tenham ilusões... a primeira forma de carne que nossos antepassados comeram era carniça, porque não tinham força para disputar o animal vivo. Não tinham nem a rapidez, nem o golpe, nem a mandíbula para matar animais, provavelmente.

Então, faziam como fazem as hienas, os chacais, então disputavam com a hiena, com o chacal, com o abutre, com o urubu o bicho já morto, muito provavelmente. A condição era essa, essa é a natureza. Muito bem. Provavelmente, muitos que tentaram a vida no solo acabaram nos 
dentes dos tigres, dos leões, e não sei mais o que de grandes felinos. Mas os punhados que lograram sobreviver, e que tiveram, digamos assim, por sua conformação, que é aleatória, que depende da mecânica genética, que em si não tem nada que ver com as condições do meio ambiente, portanto é aleatória, uma coisa não está ligada, não é consequência da outra... os que lograram sobreviver, digamos, aprenderam a correr bastante, a adquirir algo que o homem já superou praticamente todos os demais viventes, que é a chamada visão estereoscópica, olhar à distância, andar reto, ver mais longe e olhar à distância, isso é importante. Sobretudo, ao se acostumar a andar à bipedia, andar sobre as pernas, certamente o rabo caiu. Em algum momento o rabo se tornou totalmente inútil e a tendência foi ficar sem rabo, no sentido próprio do termo. Mas sobretudo, o grande salto evolutivo, por consequência lógica, nessa lógica aleatória de evolução, foi o que, foi liberar a mão. Porque todos os demais primatas, nossos primos na (...), mesmo o gibão, o gorila, que andam, são capazes de (...), mas não tem o centro de equilíbrio, de vez em quando usam a mão para equilibrar, eles não liberam realmente a mão, não especializam a mão. A plena bipedia estimulou, nesses hominídeos (...), essa total liberação da mão, e mais adiante, liberou também, e infelizmente eu quando era moleque faltei em muita aula de anatomia e de biologia, infelizmente, hoje na minha idade avançada lamento isso, não ter uma formação sólida em anatomia, aí são os soviéticos que estudaram essa hipótese, que também andar de pé libera a traqueia, libera a garganta, a laringe e a traqueia. Qual é a consequência disso? Facilitar justamente essa característica que o homem tem. (...) Mas que justamente os nossos primos, primatas não têm. Que é essa fala articulada. Ah, ô, ê, pê... nós temos, eles são incapazes de fazer isso. Que também andar de pé liberou a traqueia, então criou pré-condições, sendo bem científico, não estou aqui caindo naquele negócio da teleologia (...) aconteceu o que tinha que acontecer (...) o vício do conhecimento é esse... criou pré-condições para que mais tarde, num outro (...) de conhecimentos, esses animais que tinham, que andavam, que tinham a bipedia, essa espécie de hominídeo, de pré-hominídeo que tinha a bipedia desenvolvesse a linguagem.

Mas foi sobretudo a sinergia mão-cérebro que foi decisiva. Essa sinergia foi tal que é muito difícil dizer o que foi mais importante no homem. O cérebro, o desenvolvimento do cérebro, ou o da mão. É muito difícil dizer. O mais certo é dizer que um ajudou a desenvolver o outro. Foi a destreza crescente para raspar, golpear, romper, jogar, lançar, essa destreza crescente (...) o gesto, por exemplo, de procurar ali uma pedra para poder raspar, abrir, cortar a pele espessa do animal, isso evidentemente vem do ato inteligente de pensar nesse objeto antes. 
Também é altamente provável que a partir de um certo momento de desenvolvimento dessa sinergia mão-cérebro, os gestos técnicos foram se aprimorando, estimulou o desenvolvimento da linguagem. Pelo menos há várias hipóteses de quais teriam sido as situações que propiciaram a invenção da linguagem.

Há duas principais, que eu vou evocar em seguida. Todos aqui já ouviram falar certamente, aqueles que frequentam museus de antiguidade já viram, a evolução da técnica humana que é a tal da era da pedra lascada e da pedra polida, todo mundo já ouviu falar nisso. A diferença é brutal. 0 tipo de vivente, o tipo de nível mental e técnico que tinha aquele que fazia a pedra lascada era muito anterior ao da pedra polida. Como é que se lascava uma pedra, quer dizer, que ato de inteligência pressupõe lascar uma pedra? Claro que supõe um ato de inteligência, porque se eu vejo ali uma carniça, por exemplo, eu digo, vou ter que raspar, eu vou comer não tenho dente para... vou ter que quebrar (...) um animal de uma pele muito espessa, um elefante, sei lá eu, ou um bisão, qualquer um, então eu tenho que raspar. Então, o ato de raspar eu preciso de um instrumento cortante. No nível da pedra lascada, obter esse instrumento... o nível mental de técnica era o seguinte: ele pegava uma pedra da qual ele queria tirar a lasca e jogava em cima de uma outra, que é o modo mais elementar de partir uma pedra. E aí você fazia isso uma, duas ou três vezes até obter um instrumento, um objeto que tivesse um formato próprio para raspar a pele do bisonte (bisão ou bisonte?). Mas vocês entendem que a fabricação, a produção do instrumento era aleatória. Ele rachava, estraçalhava, quebrava a pedra de várias maneiras e ele ia ali pegar a olho, ao acaso, aquela pedra que mais serviria.

Veja a diferença entre isso e o estágio de desenvolvimento em que a população de hominídeo já é capaz de pegar esses estilhaços, pegar outro instrumento longamente analisado, estudado etc. Isso supõe não apenas uma destreza técnica. Isso supõe também que esse vivente, esse animal, escape do contexto biológico imediato. E isso é próprio da evolução cerebral. E há duas condições para que ele possa escapar do contexto, da situação biológica imediata. Duas condições. Uma que não vá morrer de fome, se for morrer de fome não tem tempo. Ele está na situação, ele tem tempo para roer o que aparecer pela frente. Então, supõe um certo controle do meio circundante, um bom equilíbrio ecológico em que o alimento está razoavelmente acessível. E supõe também a capacidade intelectual que, estando com o tempo livre, já que não precisa, não está desesperado atrás de alguma coisa para morder, que seja capaz de antecipar o que prevê. Eu já comi esse touro, esse bisão, esse elefante, mas mais para frente eu vou ter fome de novo. Então é melhor que aquele instrumento que eu já usei, que eu use de novo, que eu faça um melhor ainda. 
Eu não vou me estender nesses exemplos, de qualquer maneira qualquer bom manual de história do homem contém isso. Não é esse o meu objetivo central. Meu objetivo é: como Marx considerou essa trajetória do hominídeo. Duas considerações preliminares sobre como Marx considerou essa história do hominídeo. Primeira: a obra maior, a grande obra teórica de Marx, a maturidade, preenche 30 anos de intensa atividade intelectual. Mas nem sempre, porque ele tinha dificuldades financeiras muito grandes, nem sempre podendo se concentrar no trabalho teórico... foi ser jornalista... tinha que se virar para sobreviver. Em todo caso são 30 anos. Mas esses anos, esses 30 anos, ele esteve concentrado na sua descoberta teórica fundamental que foi a explicação da evolução econômica das sociedades. Explicação da base material da história da evolução da humanidade. E isso não é pouca coisa. Um esforço intelectual imenso o consumiu, ao escrever sobretudo a sua obra maior, ele ficou 15 anos nisso, tentando escrever 0 capital, uma primeira versão, uma segunda.

O seu capital intelectual inteirinho ele gastou para escrever O capital. E ainda assim deixou inconcluso, que é uma obra colossal, gigantesca. Nesse período, ainda que ele tivesse tempo para estudar a arqueologia, a arqueologia estava nascendo... Contemporaneamente, em meados do século XIX, muitos ainda, sobretudo aqueles que estavam impregnados da ideologia religiosa (...) com a cavidade ocular deste tamanho, e todos aqueles traços de crânios antigos, que inequivocamente dizem "isso aqui é parecido com o homem, mas não é o homem", porque o homem tinha um buraco ocular assim, ou aquilo que se diz a "fronte fugidia", que também é outro traço anatômico pré-humano, em vez de ser como o nosso que, cada um de nós, nós da nossa espécie, formamos um ângulo reto entre o corpo, a cabeça e a testa, nós tendemos ao ângulo reto, os nossos antepassados, como também os outros primatas, eram uma espécie de escada, a testa era como se fosse uma ladeira, e o alto do crânio ficava lá atrás. Descobriram grandes crânios assim, havia também uma grande população pré-histórica na Europa, antes de buscarem na África, onde estavam os mais interessantes, e também os mais arcaicos vestígios, já havia na Europa. Então como eles explicavam, com duas aspas de cada lado na explicação deles: "eram monstros".

Alguém com um olho desse tamanho, ou alguém com três mãos ou cinco orelhas. Eram monstros. Ainda havia gente, no tempo de Marx, que ao encontrar um fóssil humano, ou um fóssil de algum animal desaparecido, dizia: "isso aqui é um monstro". Porque ainda estava com aquela ideia, que aquela ideia que vinha da bíblia, do ocidente cristão, de que o mundo tinha sido criado faz 5 mil anos, 6 mil anos, que foi Deus que criou cada espécie animal, depois todas elas embarcaram na Arca de Noé, então teve o Dilúvio... eu só não entendi até hoje se os peixes também 
embarcaram com o Dilúvio na Arca de Noé, mas isso é uma dúvida mais para os especialistas do ramo, eu entendo pouco disso. Mas o fato é que, já estava tudo prontinho. Então, eles viam um negócio que não entrava em nenhuma daquelas classificações e tinham que inventar um monstro, um erro da natureza, é um monstro. Então o nível de conhecimentos arqueológicos era muito primitivo, elementar.

Esses dois limites, isto é, de um lado ele estava empenhado em explicar a evolução econômica da humanidade, fundamentalmente explicar esse modo de produção que tomou conta, que vinha a tomar conta do planeta, porque não precisou esperar o ano de 2010, em 1850 esse capitalismo está absorvendo tudo e está se desenvolvendo em escala cada vez mais ampliada, vai dominar o planeta, à sua maneira, vai submeter todas as outras formas de economia à produção capitalista, em que quem trabalha é o assalariado e o dono do capital compra o trabalho dele, compra as máquinas e ele está na mão do dono do dinheiro, do dono da grana, do cara que tem a grana. Esses dois limites fazem com que ele nunca tenha se proposto a explicar a origem do primeiro homem, como nasceu o primeiro ser vivo que pertence à nossa espécie. Isso não era o tema dele. $E$, no entanto, ele é obrigado, n'O Capital, ao discutir o conceito de trabalho, e claro que tendo em vista o trabalho assalariado, tal como existia em seu tempo, ele é obrigado a fazer algumas considerações sobre o trabalho em geral. E ele as faz com muita lucidez, com uma extraordinária lucidez e cuidado, considerando sobretudo o estágio dos conhecimentos arqueológicos, que é do tempo dele. Por exemplo, ele diz no capítulo 5 do primeiro livro d'O Capital, onde ele discute o processo de trabalho, que não vai discutir aqui o trabalho enquanto ele tem aquela forma instintiva, ele é instintivo nos demais animais, nos demais viventes, seres vivos. O trabalho no Capital o interessa tal como ele aparece nas sociedades modernas: o trabalho assalariado sobretudo. Esse é o que eu vou discutir. Mas, diz ele, o que é próprio ao trabalho humano, o que seria? Ainda assim, ele se sentiu obrigado a dizer o é próprio ao trabalho humano.

E ele diz: as formas de trabalho que ultrapassam a forma instintiva. Mas que seria uma forma instintiva do trabalho? Toda a atividade vital, todo o dispêndio de esforço que os viventes realizam para manter sua vida. E as espécies de maior desenvolvimento cerebral e físico, ou maior adaptação às suas condições desenvolvem capacidades de precisão para construir o seu meio ambiente que são notáveis. Discute nesse capítulo 5 d’O Capital, quando está tentando aprofundar o conceito de trabalho, ele fala do capitalismo em geral e da noção de trabalho em geral, ele compara o trabalho humano, ele diz "vamos pegar duas formas perfeitas de trabalho da natureza", podia usar outros exemplos, mas ele usa a colmeia e a teia de aranha. Ele usa esses dois exemplos. E aí, do modo 
como ele usa os dois exemplos, há uma discussão que é interessante e que é uma discussão que nos permite aprofundar o conhecimento dessa categoria marxista. Porque ele diz, ele chama a isso o trabalho especificamente humano é distinto do trabalho precioso da abelha e da aranha. E diz: o mais habilidoso tecelão humano seria incapaz de construir uma teia de aranha com aquela fineza, precisão e força que a aranha faz. O melhor arquiteto seria incapaz de produzir uma colmeia com as qualidades, qualidades que vocês sabem que também são geométricas, do modo como ela é feita, com o equilíbrio, com a funcionalidade de uma colmeia, como fazem as abelhas. Qual seria então, pergunta ele, e isso é uma pergunta um pouco velha na metafísica, qual seria então a diferença entre o animal e os homens? Entre o trabalho humano e os demais? O que seria o trabalho propriamente humano? E ele dá, n'O Capital, uma resposta um pouco rápida, que pode ser mal interpretada e foi mal interpretada sobretudo por aqueles... bom, claro que quando eu digo mal interpretada quero dizer que é uma interpretação que não me convém, evidentemente, que eu acho errada, evidentemente, não precisa nem ficar insistindo nisso... porque ela se parece muito, numa primeira leitura, num primeiro olhar do texto, se parece muito com as velhas explicações metafísicas, sejam elas teológicas ou não. Ele diz: o melhor arquiteto que perde para qualquer bando de abelhas, ou o melhor tecelão que perde, que não tem essa capacidade que têm as aranhas, há uma diferença, é que antes de construir a teia, uma parede, um muro, ou antes de construir a colmeia, com favas, com mel, etc., ele a representa, a casa que ele vai construir, ou o tecido que ele vai tecer, no seu cérebro. Isso distingue o artesão, o tecelão, ou o arquiteto, o engenheiro, daqueles animais que têm uma excelência, a evolução da espécie lhes deu um nível de excelência naquela produção do seu habitat. Na produção do seu habitat, porque a colmeia é a abelha que faz. Quando não havia abelha, também não havia colmeia na natureza.

Essa diferença, a mim, eu sempre tive uma forte tendência a ter concepções materialistas em filosofia, mesmo em relação ao Marx. Porque para mim o materialismo, a posição materialista em filosofia é conhecer a objetividade, a natureza e a ciência, esse sempre foi o meu lado. Não acreditar em conversas transcendentes. Também vai um pouco pelo meu temperamento, quem sabe. Fui um menino de uma educação católica, pelos jesuítas. Então não venham me dizer que eu nunca ouvi a outra versão. Eu ouvi bastante, até demais. Mas enfim, me incomodava isso. Mas por que é que me incomodava? Então o trabalho é propriamente humano porque está na consciência? É porque eu represento esse trabalho? É uma ideia? ... então isso é propriamente humano? Aí me vem a seguinte dúvida: imaginemos uma bela praia, cheia de coqueiros, não precisa ser uma praia, porque coqueiro dá fora de praia também. Nós temos aqui o vivente da nossa espécie, o homo 
sapiens sapiens, e o macaquito. Ambos sobem, não simultaneamente, no coqueiro para catar um coco. O primeiro vivente, como era um humano, ele fez um trabalho propriamente humano. E o macaquinho? Fez a mesma coisa. Ele viu o coco, estava com fome, subiu e pegou o coco. Ele também, na mente dele, que é uma mente um pouco mais turva que a nossa, ele também viu. $\mathrm{Na}$ sua percepção ele viu, e outros viventes também veem, alguns veem muito melhor do que a gente, muito mais fundo. Então, seria o mero ato de consciência, o fato de estar consciente que distinguiria o trabalho humano? Nós temos uma primeira resposta disso, na geração do Marx, um pouco depois, foi o opúsculo escrito pelo seu amigo, parceiro e companheiro inseparável Friedrich Engels. Ele tem um pequeno opúsculo, cuja leitura eu sempre recomendo, em algumas coisas pode ter sido ultrapassado, porque ele escreveu isso há 130 anos atrás, mas o que é notável é que embora ele tenha escrito isso há 130 anos atrás esse texto permanece tão fundamental, válido, e oferece pistas de compreensão.

Traduzindo do alemão, uma língua que tem uma lógica própria, muito difícil de traduzir, em geral se traduz "O papel do trabalho na transformação do macaco em homem". Na verdade nós sabemos hoje até pelas descobertas da arqueologia, da primatologia arqueológica, que o homem não descende do macaco. Macaco é um ramo que tem um ancestral comum. O que nós temos em relação aos chimpanzés, primatas, maiores ou menores, são ancestrais comuns, e houve separações sucessivas. Isso está suficientemente provado no terreno científico. De modo que aquela objeção que uma famosa lady inglesa, não era a Thatcher, mas era mais ou menos como ela, quando soube das ideias de Darwin, ela resumiu assim: Ah, esse Darwin está dizendo que eu descendo do macaco? Pode ser que a família dele sim, a minha não. Na realidade, nenhuma família descende do macaco, diretamente. Nenhum de nós, nenhuma família rica ou pobre descende do macaco. Descende, repito, ele e o macaco de um ancestral comum, que pode ser um Ramapithecus, ainda no tempo do primata puramente arborícola.

Então, aquele texto do Engels vinha resolver essa insatisfação que aquele texto curto d'o capital dava. Não preciso justificar Marx aqui, ele estava com pressa e o objetivo dele não era fazer a pré-história do homem. Faltavam elementos científicos. Como ele tinha uma posição filosófica materialista, ele disse: “Não, o homem não é um ser que caiu aí, uma essência, não. O homem é o resultado de uma evolução". Ele tinha uma noção disso. Mas não tinha conhecimento que permitisse ver em que consistia exatamente essa evolução. Ele via os outros animais labutar para viver, lutar para viver, construir, caçar (...) todos os viventes se esforçam para tirar da natureza o 
seu meio de subsistência. E aqueles que não conseguem são exterminados. É muito cruel. A lei da natureza é muito cruel, é muito simples.

A leitura desse pequeno opúsculo que eu volto a recomendar "O papel. do trabalho..", Anteil, que em alemão seria, literalmente, mas é um português horroroso, a parte, a participação do trabalho (Arbeit), na hominização, no tornar-se homem do macaco, dá um português horroroso, mas literalmente seria isso. O papel, a parte, a participação do trabalho no tornar-se homem, no processo em que o macaco se tornou homem [Anteil der Arbeit an der Menschwerdung des Affen]. Já disse porque não é o macaco exatamente, o ancestral do macaco. O Engels estava muito velho, está quase no testamento científico, está quase, faz parte... como é um opúsculo muito pequeno não circulou em pequenas brochuras, e está incluído ou na Dialética da natureza, Anti-Dühring, um dos textos que reúnem, que mais tarde foram editados, é um texto de editor, não sei se é Dialética da natureza ou Anti-Dühring. Em todo caso, quem tiver curiosidade, é só ir nessa encarnação recente da sabedoria divina, ou do espírito absoluto hegeliano que é o Mr. Google. Vai no Google que tem tudo lá. Vocês colocam Engels, trabalho, macaco, natureza, e pronto. Vocês encontram lá certamente várias edições desse texto, desse opúsculo, em várias línguas, em vários idiomas, o original no alemão. Poderia ter escrito em inglês porque o Engels morou muito tempo na Inglaterra e falava inglês tão bem quanto alemão, mas no caso o original é em alemão. Nessa leitura há uma ênfase muito forte nisso que eu chamei a sinergia mão-cérebro na hominização, essa conexão extraordinária.

Vale a pena desenvolver esse ponto um pouco. Em algum momento, na longa evolução préhistórica, terá relampejado um longo facho de luz no cérebro do hominídeo, seja ele em que estágio for, no ano 2 milhões, ou um milhão e meio, ou mais adiante, já com o gênero homo, o que terá relampejado? As primeiras ideias do que? Não é a representação abstrata... estou vendo o corpo lá no exemplo que eu dei. Estou vendo um corpo, estou vendo um pé, estou vendo caveira, não. É a imagem, o esquema abstrato da função, que função? Quais as funções que eles exerciam na luta pela sobrevivência, esses nossos ancestrais? Raspar, cortar, furar, esmagar, lançar, moer, polir... polir mais tarde, como eu já falei... a idade da pedra polida é bem posterior... foi preciso um reforço de gerações e gerações para que isso fosse absorvido, se tornasse uma norma cultural daquela população.

Foi a partir do processo mental de como vou fazer para construir, construir instrumentos, ferramentas. É importante até, do ponto de vista conceitual, não confundir instrumento com 
ferramenta. Instrumento é qualquer corpo, distinto do meu corpo, que eu uso para obter algum resultado. (...) Muitos viventes, nem se fala dos primatas, fazem muitos instrumentos, instrumentos que são incontáveis. Quando a andorinha, quando o passarinho pega um pouquinho de uma erva ou uma palha para fazer um ninho, aí não sei nem se a gente vai chamar de instrumento, porque é o corpo dele, o bico é o corpo dele. Já é um estágio avançado você poder pegar um objeto diferente do seu e prolongar o poder do seu próprio corpo. Mas ferramenta é outro salto evolutivo. A ferramenta é: eu representei a função mental, eu quero raspar, polir, furar, cortar, matar o meu vizinho. Vou fazer uma faca, um negócio contundente, que eu possa pegar na mão, isto é... quando o hominídeo, o homem se torna capaz de representar na sua mente a forma mais adequada, a função mais adequada e tem a mão tão hábil que já é capaz de imprimir na pedra, no osso, no pedaço de madeira, imprimir aquela forma que ele já representou. O que corta melhor? Tem que ser um negócio assim, pontudo. O que esmaga melhor? Tem que ser um troço... se tiver um cabo, então... uma pedra bem grande, mas se der para pegar... se eu conseguir enfiar uma haste no meio da pedra, arrebenta mais...

Então, o que Marx quer dizer com "o arquiteto representa na mente a casa que ele vai construir" é nesse sentido que ele representa. Ele tem o processo de construção da casa na sua mente. E como ele tem o processo, então ele pode discutir, pode aprimorar, perguntar para o colega dele que é engenheiro... "olha, está faltando aqui, o que que você acha? Faz o pé-direito desse jeito? Faz uma janela bem alta?". Você pode discutir o projeto, ele é suscetível de entrar no discurso e na linguagem. Então, esse é o ponto que me esclareceu a interpretação que podia ter, assim, daquela forma do Marx de que o que distingue a pior abelha do melhor arquiteto, ou a pior aranha do melhor tecelão, é que aquele tem na cabeça... não, não é que está vendo, não é isso... é que ele tem na cabeça o processo, a máquina que vai construir o tecido. E aí ele vai ser capaz de fazer, não algo tão primoroso quanto a teia de aranha, como até hoje a bioquímica se baseia em fatos naturais tentando reproduzir. Vocês sabem disso. Sabem também que a medicina com todos os colossais avanças que obteve não consegue avançar um passo, por exemplo no sistema nervoso central, tem doença nervosa que você não cura. Ainda não tem como. Não sei se daqui a dois séculos, já não se dirá mais isso. Mas hoje, eu tenho que dizer isso. (...)

Esse é o sentido materialista, que Marx entendeu. Ora, aquela posição de interpretação do marxismo que eu disse que eu critico, que eu recuso, e que eu acho que é uma redução metafísica no terreno da objetividade, seria dizer essa (...). Porque o homem tem o trabalho, já é um atributo essencial do homem, da "essência genérica do homem", o tal do Gattungswesen do Feuerbach. 
Quer dizer, o homem já surgiu dotado desse atributo essencial que é o trabalho, e o trabalho é a exteriorização da essência genérica do homem. Esse tipo de discurso, muito em voga no meio marxista, mais no Brasil, mas também até fora do Brasil, ele inibe, eu acho, a descoberta científica, a problematização científica. Além de colocar problemas filosóficos, mas esse não era o nosso tema. Eu digo colocar problemas filosóficos, que é o argumento que eu sempre retomo, para compreender um autor, nós temos que respeitar a linguagem dele. E muitas vezes os estereótipos, os manuais, os esqueminhas que fazem de certos pensadores vem sempre... por exemplo, Hegel: Hegel é um autor difícil, complexo, e uma leitura que quando você vence aquela primeira barreira, é uma leitura extremamente gratificante, extremamente plena de recompensas intelectuais para quem faz o esforço de chegar lá. Sobre a dialética hegeliana: é tese, antítese e depois a síntese (...). Hegel, dialética... francamente. A palavra dialética, você encontra. Mas quem lê o texto do Hegel, você encontra vinte vezes mais a palavra Logik-“lógica”, ou "lógica objetiva”, do que dialética. Sim, não está dizendo um disparate, dizer "dialética hegeliana" não é dizer um disparate, eu não estou dizendo isso. Eu estou dizendo: não é uma palavra chave no Hegel.

Agora, no caso do Marx, os que falam, querem compreender o marxismo a partir de uma pretensa ontologia do ser social, o primeiro desrespeito, e isso eu disse até um amigo meu, que morreu há doze anos atrás de enfarte, que era o José Chasin, e que era um dos que defendiam isso. Eu disse, Chasin, a primeira preocupação nossa é respeitar o texto. As obras de Marx e Engels ocupam hoje na tal Marx-Engels Gesamtausgabe (MEGA) já está em cem volumes, feitos por eruditos, especialistas do mundo inteiro, estão na Alemanha, hoje, fazem isso na Alemanha, morando na Alemanha, (...) este instituto que faz a edição da obra completa. Nesses cem volumes, você encontra duas ou três ocorrências da palavra ontologia, sob a (...) de Marx. Ocorrência nos textos de juventude, sem nenhuma importância particular no uso desse termo. E ele conhecia muita filosofia, tinha uma belíssima cultura filosófica. Se ele não empregava o termo, é porque ele achava que o termo era impróprio para expressar a sua posição filosófica e a sua posição científica. Aí vem, 90 anos depois, um pensador húngaro chamado Lukács, que tem coisas interessantes, e que resolve dizer que o fundamental para explicar o pensamento de Marx é a ontologia do ser social. Usando um termo que Marx usou duas vezes em 50 anos, em 60 volumes. É uma palavra chave, uma ontologia, e por que ele nunca usou? Porque a palavra ontologia era uma palavra do idealismo, e não era de qualquer idealismo, do idealismo de Leibniz, que era um pensador, vocês sabem, ligado aos jesuítas. Um grande matemático... quando a gente critica alguém não está querendo... longe disso. É um pensamento idealista.E na Alemanha do século XX, na qual vivia Lukács, e que ele 
escolheu isso, o grande pensador que ativou esse termo, e que é um filósofo de grande estatura, queiramos ou não, gostemos ou não, mas que é muito... foi Martin Heidegger... aí não estou dizendo que ele foi membro do partido nazista, bom... aí ele foi membro por oportunismo, o pensamento dele não se confunde... não é indiferente, mas também não se confunde. O que ele diz, o argumento dele.... aí tem que ver o argumento dele. Isso aí de "não", "não vou ouvi o argumento dele porque ele foi do partido nazista", isso é uma atitude também dogmática, vamos ver o que ele diz, o que ele tem a dizer sobre a noção de verdade nos gregos antigos. Vamos ver a filosofia dele antiga. É até que tem alguns insights filosóficos. Ele não precisa de mim, João Quartim de Moraes, para provar que o Heidegger é importante. Realmente dispensa a minha avaliação. Mas de qualquer maneira a minha opinião é essa: ele tem uma estatura como pensador (...) (prometo a vocês, por Alá, que estou nas minhas últimas considerações).

Então, no fundamental, ela é um desvio filosófico, cujo criador é esse filósofo húngaro marxista, mas é um marxismo muito marcado por seu hegelianismo idealista, e que justamente essas questões, e que a questão da origem do homem e do primeiro homem são questões totalmente irrelevantes. Porque o que importa é essa essência genérica do homem, a tal da Gattungswesen, e da qual trabalha a primeira expressão (...). Pronto, terminei. Espero não tê-los cansado muito, e obrigado pela atenção.

Respostas durante o debate:

Eu comento rápido essas duas. Talvez eu não tenha sido suficientemente explícito dizendo: a tese de que o homem se autoproduziu pelo trabalho é um princípio do materialismo histórico. Apenas, ele por si só não esclarece tudo, porque o homem se autoproduziu não tem um círculo vicioso aí? O homem produziu a si mesmo trabalhando? Mas ele se produziu porque ele trabalhava de um modo humano? Que trabalho produziu o homem? De modo que, bom... sobre a ontologia, eu digo: ontologia é um nome... nenhuma palavra é inocente... democracia... falávamos disso hoje de manhã. Nenhuma palavra-chave, da vida cultural, da vida política, é inocente. As palavras são um campo de batalha. As palavras-chave da vida social, política são um campo de batalha. Outras são campos de dificuldade, para esclarecer. Outras são difíceis porque a dificuldade está ligada mesmo à natureza de cada processo. No caso da ontologia, eu sou contra qualquer atitude, digamos, religiosa: não pode falar desse horror de ontologia. Nada disso. Eu digo: nós temos que ter consciência, primeiro, que Marx não achou necessário para se expressar filosoficamente, não é 
só n'O Capital, de utilizar esse termo, e Marx conhecia muito bem filosofia. Dois: Marx fala sim em ser social, mas em ontologia do ser social ele não fala. E ser social quer dizer que o homem é gregário, é coletivo. O homem isolado é uma abstração. É um milionário que compra um iate e vai passear pelo mundo. É um produto raríssimo da exploração de classes e da desigualdade social. Ter uma cobertura no quadragésimo andar de um imóvel moderno. Também é isolar-se. É sempre um produto social isso. Difícil (...) o isolamento. Eu acho que (...) deve falar em ontologia, não é isso. Muitas vezes traz pronta a explicação, é isso o que me incomoda. No início da humanidade, o homem é um ser genérico, coincidente, harmônico, a natureza humana estava lá, o homem... seria quase como um mito do paraíso, ou do Rousseau, o bom selvagem do Rousseau... não havia crimes etc.

Aí veio a questão da mercadoria, a opressão, o homem se dividiu, um passou a explorar o outro, alienou o trabalho, aí a humanidade está fragmentada. Um: (...) a felicidade paradisíaca, a essência do homem está ali (...). Dois: o homem perde a sua essência, se aliena. Três: no final da história, na radiosa aurora do comunismo, ele vai se reconciliar com o seu (...). Eu acho que a primeira parte é falsa. Que os primórdios é até mais duro do que agora. Era bem mais duro ali os primeiros pitecantropos que desceram da árvore e estava ali de noite, tinha predador diurno, tinha predador noturno, o medo de morrer, de ser engolido, quer dizer, é terrível. A condição humana era bem pior. A fraqueza do homem perante seu meio, o seu ecossistema. Quanto ao futuro, aí é outro assunto. $\mathrm{O}$ que você tem é um ideal de humanidade. Agora, o importante do ideal é que ele tenha alguma relação com a realidade. Senão fica masturbação mental, devaneio, delírio. Mesmo quem não consome droga, é o mesmo efeito. Você fica sonhando com alguma coisa que não é. É um direito, todo mundo tem esse direito. Mas não no combate político. No combate político ele só atrapalha. Preconizar uma evolução da humanidade ou (...) sem relacionar com as condições do que é a humanidade hoje... bom, tem a palavra utopia, para dizer isso também. Mas aí a palavra utopia (...) incita a passividade, ou ainda o que é pior, incita uma hiperatividade sem bases objetivas e quem tenta se estraçalha. Por isso que é bom a vontade de mudar o mundo conhecendo o mundo. Sem o conhecimento do mundo a vontade de mudar o mundo é cega.

Sobre o instrumento, eu muito rapidamente distingui: o uso do instrumento é comum a muitas espécies vivas. Ele corresponde a um estágio anterior, digamos, a um estágio rústico da evolução biológica. Quantas espécies não são capazes, sobretudo entre os primatas a gente vê isso sempre... eu ia usar o exemplo clássico dos chimpanzés e dos gorilas que querem comer aquela formigona gorda cheia de proteína, enfia uma vara no formigueiro e puxa a vara carregada de 
formigas. Ele está usando um instrumento. Eu distingui isso de quando, a espécie animal usa seu própria corpo, é diferente. Podemos até dizer dialeticamente ele está usando o seu corpo como instrumento. Se eu dou um soco aqui, estou usando meu braço como instrumento, como um martelo. Na verdade, confunde um pouco, porque o meu braço não é um martelo. O meu braço fechado, a minha mão fechada, e se eu golpear forte, certamente em algum momento da evolução inspirou o martelo. Inspirou a faca, a navalha, lógico, os gestos. Esses gestos que depois o hominídeo se tornou capaz de traçá-los, imprimi-los na pedra, no osso, ou na madeira, que eram os principais instrumentos de fabricação. A representação mental pressupõe o domínio da função técnica. Quer dizer, é depois de raspar muito, sem pensar muito, com o cérebro meio apagadaço, é que o hominídeo foi sendo capaz de ver que o que eu estou fazendo aqui para tirar, para raspar a pele, que esse gesto, vinculado sempre a um instrumento, que vai fazer isso melhor do que minha mão, o raspador, então eu invento o raspador. Mas o que quer dizer eu invento o raspador: quando você vislumbra o gesto técnico que imprime aquele resultado na matéria você já tem quase, não vou dizer uma palavra, mas você tem uma imagem mental. Essa imagem mental é o primeiro para você usar para construir algo, para você, na memória, conservar esse algo com um nome. Não deviam ser palavras prontas, como as nossas, mas grrrhhh, crrrhhhh, brrrhh... estou inventando aqui, não é nenhuma gravação de hominídeo, não é? Não sobrou... quem sabe um dia descobrem que algum som ficou gravado, sei lá... Não sabemos. Mas certamente eram as primeiras formas articuladas da linguagem. Então, você tem a ideia, a palavra que é alimentada pelo gesto técnico reiterado, que leva à fabricação do instrumento. A ferramenta é um instrumento fabricado pelo usuário. E não mais aquele que o sujeito apanha na situação biológica imediata. Por isso que eu disse: ele pressupõe que a inteligência humana tenha se emancipado, que tenha adquirido uma certa distância em relação à situação biológica imediata. O que significa várias coisas: ele não está morrendo de fome, não está morrendo de sede, não está sendo acuado, não está sendo caçado por um predador maior, tendo que fugir, esteja com a barriga razoavelmente cheia. Então possa gastar uma parte do seu tempo e ao mesmo tempo tenha uma lucidez mental, em vez de ficar coçando aquela parte lá, ou amolando os outros, ou dormindo, pensar naquele raspador que permitiu dar aquela mordida deliciosa na carne crua do elefante; quero ter esse negócio quando o próximo elefante cair morto por aí, eu vou fazer a mesma coisa. Tudo isso são processos que demoraram milênios, evidentemente. Não foi um cara que acordou e "Opa!", "vou fabricar" ... "oh pessoal, chega de usar instrumentos, vamos agora produzir ferramentas" ... Seguramente nunca houve esse momento. Aí nós temos aquela dialética do contínuo e do descontínuo. Em algum momento alguém descobriu o troço (...) Vamos dominar o fogo. Primeiro, usar o fogo, alguns começaram a ver que 
podiam conservar o fogo, na caverna... a partir de incêndios naturais. Depois um mais esperto foi vendo aquele jeito complicadíssimo de produzir chamas. São descobertas que levam 10, 20, 50 mil anos... 100 mil anos, o que pressupõe que aquela população sobreviva 100 mil anos, para transmitir aquele pequeno conhecimento para a geração seguinte. $E$ as gerações eram muito curtas naquela época. A esperança de vida era de 20 anos, 25 anos.

Não devia ser muito mais do que isso. Bom, então eu vou terminar o primeiro ponto sobre a noção de trabalho propriamente humano. Eu acho que na sua questão já há uma problemática, digamos, filosófica. O homem não trabalha para se expressar, ele trabalha para sobreviver. 0 trabalho era o modo que ele tinha de sobreviver. A diferença entre trabalho vivo e trabalho morto n’O Capital, ele chama trabalho morto o trabalho que já está cristalizado nos produtos do trabalho. Por exemplo, ele diz: numa fábrica, o trabalho vivo é aquele que o assalariado, o operário está ali, o esforço que ele está despendendo naquele momento na máquina. Agora a máquina, ela própria, é fruto de um trabalho anterior. Alguém teve que produzir aquela máquina. Ora, já foi produzida a máquina. A máquina entra como trabalho morto na contabilidade da empresa, na dinâmica da empresa. Porque é um trabalho já realizado, já gasto, que está ali.

Muito bem, obrigado pela pergunta. Eu li muita coisa do Lukács ao longo dos anos e nunca consegui grudar muito na leitura do Lukács, mas isso é um problema meu. Mas ele escreveu muita coisa, ele tem uma obra muito variada. Textos políticos, conheço os textos políticos dele, $\mathrm{O}$ assalto à razão, que é um livro interessante, aquilo que eu disse da ontologia não é para o Lukács, Lukács é um homem interessante, pensador de estatura, acho que essa invenção dele teve efeitos desastrosos, mas isso não tira a estatura do sujeito. Mas a observação dela me ajudou. Você tem razão em observar esse ponto porque, primeiro, eu nunca li no Lukács aquilo.... Eu imputei... mas para o Feuerbach, que para o Feuerbach, mas o Lukács, se vivesse ... numa sessão espírita chamasse o Lukács aqui ele ia dizer: não, espere aí, você não tem o direito de me atribuir as ideias do Feuerbach. Então para não ouvir essa possível reclamação de nosso companheiro Georg Lukács, então tudo bem. Ele não diz que havia um passado, eu até comparei com a ideia do Rousseau, do bom selvagem, daquela inocência primitiva, que também até no mito do paraíso bíblico, o homem estava bom ali, de repente apareceu lá perturbaram o homem, se a gente ver o que aconteceu com a humanidade hoje não é nada idílica. Não tem nenhum paraíso aí, as frutas não caem... um mito 
de explicação. No caso é uma imputação que eu retifico. Eu digo: isso está certamente na ideia da essência genérica do homem em Feuerbach. Até que ponto ao retomar a ideia da essência genérica, o Lukács encampa isso ou não eu não sei. Agora, como eu não sei, a gente não deve (...) quando não sabe. Portanto eu retifico esse ponto.

Isto dado, me chama a atenção, na construção da sua frase, que essa essência genérica compõe a humanidade. Mas aí já está... o que você entende por compor, essa potência... o que me garante que... o dado, digamos assim, objetivo, uma certeza que é fora da minha esperança, da minha imaginação, o que me garante que isso compõe a humanidade. Que o homem tenha uma essência genérica, me desculpe a rudeza da afirmação, está no nosso ácido desoxibonucléico, ADN, aí sim. Isso eu entendo. Nosso código genético eu entendo. Agora, essa essência pairando transhistoricamente é uma imaginação. Posso citar até um filósofo pré-hegeliano, Immanuel Kant, isso é um delírio da razão. É um fantasma da razão, da razão trabalhando fora do campo da experiência sensível. Então, me desculpe, usando safadamente o Kant contra você, mas não é. Mas isso um pouco. Quem comprova isso? É verdade? E como é que ele sabe que está na essência genérica do homem? Como é que ele tem essa ideia? De onde ele tirou essa ideia? Isso compõe, mas compõe em potência... E veja bem, outra objeção filosófica: se eu divido a história da humanidade entre aquilo que está em potência e aquilo que está em ato, eu estou usando o velho esquema do Aristóteles. (...)

Quartim: -- Um encontro como esse em que nós estamos queremos pensar seriamente, sem querer passar recado obrigatoriamente, é evidente que vai deixar muitas questões em aberto. Se algum objetivo eu posso tentar, além de passar algumas ideias, algumas informações, sugeri algumas leituras, é também fazer pensar, naquilo que eu disse que não fui eu que inventei, naquilo que eu expus, apresentei aqui, ótimo, ganhei, ganhamos a noite, não é? Então, as ideias se entendem de muitas maneiras. A nossa vida mental é feita de ideias lato sensu. Os empiristas ingleses chamam que tudo que está na minha cabeça são ideias. Todas as representações da minha cabeça. Claro que na minha cabeça tem neurônios, tem coisas que não são ideias. Então é um problema que é básico na filosofia, na psicologia, e também na neurologia, que é "da onde vêm nossas ideias", que há uma forte dependência de sua base material, há, nós temos a memória, não é tão mecânico assim, mas evidentemente que as ideias funcionam na base de seu suporte que é 
esse órgão especializadíssimo em produzir ideias, produzir cargas energéticas com representação que é o cérebro, o cérebro humano, que é o cérebro mais potente, mais variado, mais amplo, mais adaptado, também perverso, por isso que eu comecei dizendo "o homem é o único animal que tortura".

Então, vamos dizer que a tortura é desumana e muito humana também. Aí como dizia o famoso Nietzsche "humana demasiado humana" a tortura, perfeitamente humana. Podemos mudar o homem, aí, como dizia a minha avó, isso são outros 500 mil réis.... Mas já que a referência da sua intervenção foi as Teses sobre ou para Feuerbach, o que Marx diz a esse respeito é que é preciso levar em conta os dois lados: o lado ativo e o lado passivo. As ideias têm um lado ativo, não é um idealismo contemplativo, a ideia é ação, a ideia é plana, a ideia é uma elaboração cultural mais desenvolvida daquilo que eu disse. Aquela representação mental que o homem adquiriu ao raspar, cortar, gritar, fugir etc. Ou seria outra a origem das nossas ideias? Eu não vejo nenhuma origem para as nossas ideias a não ser a vida social do homo sapiens. Até porque a linguagem é social, a linguagem não é individual por definição, se linguagem é comunicação, a comunicação é social. As primeiras ideias estão associadas a situações existenciais decisivas. Algumas hipóteses que eu também posso evocar muito rapidamente, a conexão entre linguagem e consciência. Marx na Ideologia alemã, tem ideias interessantes sobre isso, embora ele não tenha desenvolvido, quem desenvolveu foram alguns antropólogos marxistas notáveis do século XX, embora muito pouco conhecidos, um deles é o vietnamita de cultura francesa Tran Duc Thao, autor do "Ensaio sobre a origem da linguagem e da consciência", que a comunicação por sons se desenvolveu numa situação que era decisiva para a sobrevivência dos hominídeos, dos primeiros homens. Isto é, há 200 mil anos atrás, que é a situação de caça. A caça era vital, que é a principal carga de proteína. A caça pressupõe um certo nível de desenvolvimento, eu digo caça, e não comer carniça. A caça supunha forma de cooperação no trabalho, e a caça é um trabalho coletivo extremamente avançado, envolve uma disciplina, uma tática para cercar as feras, que variava conforme o animal que você fosse caçar, armas, portanto supõe a produção de ferramentas, então já é um estágio bem avançado, já quase no neolítico, já no estágio do neolítico. Mas que a fixação da linguagem em algum momento da passagem entre o paleolítico e o neolítico, no último paleolítico, digamos, e nas situações de caça era muito frequente o grupo, naquela mata densa, (mas não se entrevistou nenhum... (...) infelizmente não houve tempo para isso... mas que era uma hipótese bastante razoável) é que na situação da caça, correndo atrás da presa, do animal, se perdiam. Já tinha uma comunicação gutural, um chamando o outro, para se localizar, para não ficar perdido na mata, e 
muitas vezes o chamado, se o grupo de caçadores estava longe, e aquele, devido a se isolar, como que se perdia, ele berrava porque não queria ficar isolado, berrava, chamava de todos os modos que ele podia, e (...) a s outras pessoas achavam-no, ou podiam não achar, e ele morria ali sozinho, sei lá eu o que acontecia com ele. Podia acontecer tudo, mais provável que (...) no isolamento, ou acabasse no dente de um tigre, dependendo da região, de um elefante, não sei do quê. Mas esse gritar, quando já não tinha resposta, isso é o primeiro relampejar da consciência. Por quê? Porque a consciência, do ponto de vista da filosofia materialista, é falar para si mesmo, é ter a si mesmo como objeto do pensamento. Então, quando eu começo a gritar e ninguém ouve, não estou gritando para ninguém, estou gritando para mim mesmo. Estou expressando o meu desespero, a minha solidão, o meu medo, minha ânsia terrível de escapar daquilo e de encontrar parceiro, para me tirar daquele buraco lá. Então os primeiros lampejos da consciência estão na reiteração, porque isso nunca é uma vez só que cria, não é? ... Uma andorinha não faz o verão... é a reiteração dessas situações de caça em que a palavra, o grito, a comunicação, e a diferenciação de grito, porque (...) o bicho tá (...) para lá... para cá... para ali... então é um primeiro elemento forte, a primeira recompensa evolutiva forte, seletiva forte, que o grupo que aprende a usar bem a linguagem da caça, caça melhor, come melhor, sobrevive mais, deixa mais descendentes. $O$ esquema darwiniano perfeito. Que eu considero Darwin um gênio da estatura do Marx. Eu considero, e muitos outros junto comigo. É isso.

De um modo pragmático eu diria que há muitas melhores maneiras de aproveitar sua leitura e estudo do que ficar especulando sobre o que é a essência humana, a menos que você tenha dados concretos, históricos, que tenha um terreno objetivo, senão você não sai das suas nuvens. Pode haver uma essência humana diferente das relações sociais, culturais da humanidade? Essas relações são contraditórias, e a contradição eu expus de um modo muito singelo, "torturar é desumano", poderia dizer muitas outras coisas, "tornar Londrina uma cidade mais humana". Por que? São gorilas que moram aqui? Não, são humanos que moram aqui. Que quer dizer tornar mais humano? Alguma coisa quer dizer...No fundo, eu sei o que quem diz isso quer dizer. Agora, está se exprimindo de uma maneira curiosa. Está achando que vai melhorar o homem? Tudo bem, eu sei que é desejável: vamos tornar o homem melhor. Aí, já não colocaria essa coisa que fica irônica, não é? Vamos melhorar o homem, vamos melhorar as cidades, melhorar as relações entre os homens, 
vamos respeitar, quem dirige, a prioridade do pedestre, numa esquina o motorista que faz conversão à esquerda, pela lei, pelo código de trânsito, é obrigado a dar prioridade ao pedestre. Pouquíssimos respeitam a lei. Então, vamos tornar o trânsito mais humano? Mais disciplinado, mais civilizado, aí eu entendo. De modo que eu não aconselharia, como velho professor aposentado, a ninguém ficar queimando pestana e gastando neurônio para especular sobre a essência humana, não é um exercício mental que eu recomendaria. Agrade você ou não, mas... você pediu minha opinião. 